Gunther, Wingate, Oughtred, Forster and Partridge. Heilbronner ("Historia Matheseos Universæ," Leipzig, 1742) includes Wingate and Gunter, while La Lande ("Astronomie," Paris, 1792) refers to Gunter as known for his scale of logarithms. These from the limited works at my hand that would bo likely to mention these men.

Gunter's "Description and Use of the Sector, Cross-staff, and other Instruments," London, 1624 (p. 2), should be, according to the British Museum Catalogue, "The description use of the sector, crosse-staffe, and other instruments." The printed title page of a copy in the British Museum is dated 1623. "Horizantal" in the title of Forster's work (p. 11) should be "Horizontall," and the title of Wingate's publication (p. 9) should begin with "The." I note three " $\lambda$ "s in the Greek word in footnote on page 21. There are omissions in the index, e. g., Mehmke and other names of the preface. Perry and Segner (preface, page iii) are hardly entitled to be called "advanced mathematicians." The given bibliography of the slide rule receives undue prominence as it is by no means complete, a fact shown by the most casual reference to the articles on the slide rule in the "International Catalogue of Scientific Literature, Mathematics," and to the Royal Society of London's "Catalogue of Scientific Papers, Subject Index, Pure Mathematics."

Especially worthy of commendation are the abundant photographic reproductions of diagrams from the originals. The most serious criticism to be brought against this publication is that it was placed upon the market with such important corrections in the addenda. Doubtless it would have been expensive to correct the fundamental errors in the text shown by the results stated in the addenda, yet the value of the work is considerably lessened by this omission. The publishers state in a footnote that copy of the addenda was received after the text was printed. It is to be hoped that some time an edition may appear in which these important conclusions are embodied in the text.

L. C. Karpinski
Birds of South Carolina. By Arthur TrezeVANT WAYNE, Honorary Curator of Birds in the Charleston Museum. With an introduction by PAUL M. REA, Director. Contributions from the Charleston Museum, I. 8vo, pp. $\mathrm{xxi}+254$. Charleston, S. C. 1910.

The present work is based primarily on the personal observations of the author continued for nearly thirty years, mainly in the coast region of the state, to which it was his intention originally to limit its scope. The introduction by Professor Rea, based largely on manuscripts furnished by the author, whose prolonged illness rendered this assistance necessary, treats of the physical divisions of South Carolina, and the history of South Carolina ornithology, which begins with Catesby's " The Natural History of Carolina, Florida, and the Bahama Islands," published in two folio volumes in 1731-48. The later contributions, by various authors, are duly noted. The main body of the work consists of a systematic list of the "Birds of the Coast Region" (pp. 1-204; 309 species), followed by an annotated list of additional species from the interior of the state (pp. 205-213; 28 species), and a "Hypothetical List" (pp. 215-222; 22 species). A bibliography of about 200 titles and a good index complete the volume.

As a faunistic contribution, it is a work of high value, the species of the coast region being not only very fully annotated, but the annotations present a summary of the long field experience of a conscientious and exceptionally careful and competent observer, enthusiastically interested in his work. The records made by other authors are not neglected ànd loose or erroneous statements receive critical attention. Mr. Wayne has largely, for many years at least, had this especially interesting field almost to himself, and since about 1886 has added over thirty species to the known fauna of the region and contributed a long list of minor papers on its birds. In bringing together in a handy volume the results of his ornithological observations, he has rendered a grateful service to his 
fellow-workers and produced a work which will always remain the standard source of information on the subject of which it treatsthe birds of the coast region of South Carolina, their relative abundance and manner of occurrence at the date of its publication.

J. A. A.

\section{BOTANICAL NOTES}

BOOKS ON MOSSES

Ten years ago Dr. A. J. Grout brought out a little book with the title "Mosses with a Hand Lens," which was intended to "give by drawings and descriptions the information necessary to enable any one-interested to become acquainted with the more common mosses with the least possible outlay of time, patience and money."

Five years later, encouraged by the reception accorded his venture the author brought out a second, greatly. enlarged edition, in which he included the liverworts also. That these little books have been most useful needs no proof here. They have made it possible for many a student to study mosses in field and forest as he studied ferns and flowering plants. Some one should give us similar books on the fungi (and lichens) and the freshwater algæ, and for seaside dwellers the seaweeds might well receive a similar treatment.

In the optimistic mood which the success of his little moss book induced, Dr. Grout projected a larger work which he began publishing in German fashion in successive "parts," under the title "Mosses with Hand Lens and Microscope." The first of these parts appeared in 1903; the second in 1904, the third in 1906, the fourth in 1908, and the fifth (concluding) in 1910. We have now the complete work, making a large octavo volume of 416 pages, including 89 full-page plates, and 220 text figures. Many of these are from Bryologia Europaea, and Sullivant's Icones Muscorum. There is no attempt to include all the mosses of the region (northeastern United States) but the author has made a judicious selection, for which his long experience as a teacher as well as a bryologist has well fitted him. The keys to the genera and species, together with the carefully drawn descriptions, make it rather easy for the pupil to find the name of any ordinary moss.

The book closes with a key to sterile specimens, and a good index. A good glossary (illustrated) is given in the introductory part of the work (pp. 37-44).

The author is to be congratulated upon the completion of this notable book, and students of the mosses will be glad to know that he offers it now as a bound book. (New Brighton, N. Y.)

\section{THE GRAY CENTENARY}

The Botanical Seminar of the University of Nebraska will celebrate the one hundredth anniversary of the birth of Dr. Asa Gray on Friday, November 18, 1910. At a general convocation to be held at eight o'clock in the evening of the above day in the botanical lecture room in Nebraska Hall, the following papers will be read:

"Gray's Writings to be found in the Botanical Library," Professor E. R. Walker.

"Gray's Manuals and Floras," Professor G. H. Coons.

"Gray's Text-books," Professor R. J. Pool.

"Gray's Influence as a Teacher," Professor E. M. Wilcox.

"Reminiscences and Letters," Professor C. E. Bessey.

The above papers will be assembled by the "Lord Warden" and printed as a publication of the seminar.

\section{THE NUMBER OF KNOWN SPECIES OF PLANTS}

IN some work upon which I have been engaged recently it became necessary to bring together in compact form what is known as to the number of kinds (species) of plants with which botanists have enough acquaintance to permit of their systematic arrangement and enumeration. The result is that roughly speaking we may say that there are now known about 210,000 species, distributed as follows:

Myxophyceae (Blue Greens) ...... 2,020

Protophyceae (Simple Algae) ...... 1,100

Zygophyceae (Conjugate Algae) ... 7,000

Siphonophyceae (Tube Algae) $\ldots \ldots, 1,100$

Phaeophyceae (Brown Algae) ...... 1,030 